\title{
CURRENT SITUATION OF COVID-19 AND VACCINATION IN PAKISTAN: JULY 2021
}

\author{
Irum Naureen (Assistant Professor), Ayesha Saleem (M.Phil Researcher), Attique Nawaz (M.Phil Researcher)
} School of Zoology, Minhaj University Lahore Pakistan

Abstract: COVID-19is thought to be expended in Pakistan. On February 26, 2020 first case was reported in Karachi. On January 30 world health organization (WHO) coronavirus outbreak on the sixth public health emergency of international concern (PHEIC)announced that coronavirus is epidemic. WHO set up an instructive program planned to control the increase rate of COVID-19 cases. COVID-19 spread very fastly from person to person within few days and months leads to increase rate of Patients. According to latest updated report 2,452 confirmed coronavirus cases were reported in Pakistan. According to the report: 49,503 test were positive: $4.95 \%$ deaths $(30$ persons died) and 903 recoveries were recorded. Overall the Active Cases 48,850 and critical cases 24 in last 24 hours reported. Coronavirus cases were reported in Punjab 350,618 deaths 10,881 and recoveries 329,756. In Sindh confirmed cases were 356,929 deaths 5,720 and recoveries 320,600 . In KPK confirmed cases reported 140,818 deaths 4,386 recoveries 134,144 . Balochistan recorded report of confirmed cases 29,110 deaths 319 and recoveries 27,261. AJK reported confirmed cases 22,116 deaths 601 and recoveries 19,995 while in GB confirmed cases recorded 7,414 deaths 117 and recoveries 6,432 . Six vaccines approved in Pakistan Sinopharm, Cansino, Sinovic, sputnik, AstraZeneca, and Moderna (mRna-1273). Pakistan total dose administered 22,735,993 fully vaccinated 4.550,696 and partially vaccinated 18,185,297. Vaccination start on 3 February and 18 above start on June 3 . It was observed that COVID-19 cases increases due to traveling from one country to another country. In Pakistan COVID-19 cases is high due to importation and traveling to meet other peoples that suffer in diseases. Pakistan need to follow high and good precautions rules and strict step in order to decrease the COVID-19 cases.

Key words: Coronavirus, Awareness, COVID-19, vaccination, doses, epidemic, Pakistan,

\section{INTRODUCTION}

COVID-19is thought to be expended in Pakistan. On February 26, 2020 first case was reported in Karachi. ${ }^{(3)}$ On January 30 world health organization (WHO) coronavirus outbreak on the sixth public health emergency of international concern (PHEIC)announced that coronavirus is epidemic ${ }^{(2)}$ COVID-19, has caused a staggering sickness with high paces of dreariness and mortality spreading everywhere on the world. The careful components through which immune system responses can be set off by immunization are not perceived, despite the fact that they likely shift concurring to the kind of antibody and individual hereditary susceptibility. ${ }^{4)}$

The world health organisation (WHO) has warned Pakistan that is the country come across great challenges in coming days against COVID19. ${ }^{(2)}$ According to health organization centre, coronavirus incidence increase due to traveling from one country to another country.

\section{STUDY DESIGN AND DATA COLLECTION}

This study is an observational study.

We arranged objectives was to increase cases of COVID-19 patients examine the confirmed cases report active cases, death rates, and recoveries data on June 22, 2021- July 19 2021. COVID-19 cases increase within few days. Data acquired electronic record using computerized database registration. This study was based on increase rate of COVID-19 cases in Pakistan. Every patient record was coded secretly, and need for guidance to insure decision making, clinical care, and public health, policy making at every level of COVID-19 responses. 


\section{International Journal of Engineering Applied Sciences and Technology, 2021 \\ Vol. 6, Issue 3, ISSN No. 2455-2143, Pages 62-67 \\ Published Online July 2021 in IJEAST (http://www.ijeast.com)}

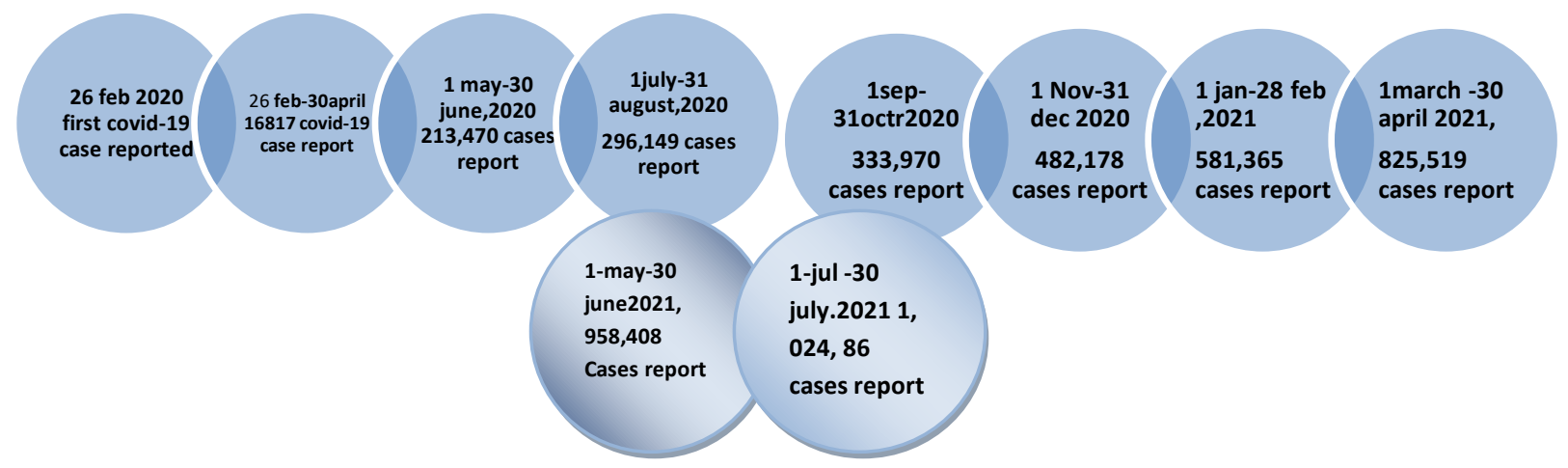

Fig 1: Represent the covid- 19 cases reported on 26 Feb, 2020- 30 July, 2021

\section{Current Situation and Epidemiological Analysis:}

In Pakistan according to 16 July 2021 report, in last 72 hours confirmed cases 986,668 active cases: 45,579 death rates $\mathbf{2 2 , 7 6 0}$ and recoveries were $\mathbf{9 1 8 , 3 2 9}$

Table 1: Pakistan current situation reported on province wise.

\begin{tabular}{|l|l|l|l|c|}
\hline Province & Confirmed cases & Active cases & Death rates & Recoveries \\
\hline AJK & 21,811 & 1301 & 598 & 19,912 \\
\hline SINDH & 354,103 & 28,580 & 5,697 & 31,9826 \\
\hline Balochistan & 28,884 & 1,412 & 319 & 27,153 \\
\hline KPK & 140,293 & 1939 & 4,380 & 133,974 \\
\hline ICT & 84,399 & 1,941 & 787 & 81,671 \\
\hline Punjab & 349,890 & 9547 & 10,865 & 329,478 \\
\hline GB & 7,288 & 859 & 114 & 6,315 \\
\hline TOTAL & 986,668 & 45,579 & 22,760 & 918,329 \\
\hline
\end{tabular}

reported140,818 deaths 4,386 recoveries 134,144.

According to Pakistan's last update on (July 19, 2021 at 07:59am) reported. 2,452 confirmed coronavirus cases were reported in Pakistan, total tests in last 24 hours: 49,503 positivity \%: $4.95 \%$ and deaths: 30 and Recoveries 903. ${ }^{(5)}$ Overall the Active Cases 48,850 and critical cases 24 in last 24 hours reported. Coronavirus cases were reported in Punjab 350,618 deaths 10,881 and recoveries 329,756 .

In Sindh confirmed cases were 356,929deaths5,720 and recoveries 320,600. In KPK confirmed cases
Balochistan recorded report of confirmed cases 29,110 deaths 319 and recoveries 27,261. AJK reported confirmed cases 22,116 deaths 601 and recoveries 19,995 while in GB confirmed cases recorded 7,414 deaths 117 and recoveries $6,432 .{ }^{(5)}$

Total Confirmed cases 991,727 Active cases: 48,850. Death rate: 22,811 (2.3\%). Total Recoveries920,066 $\mathbf{( 9 2 . 8 \% )}$ as shown in Figure 1. 
Published Online July 2021 in IJEAST (http://www.ijeast.com)

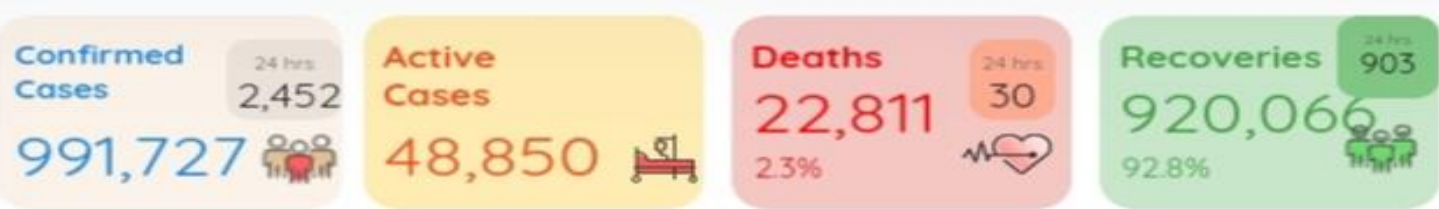

\begin{tabular}{l|c|c|c|c}
\hline & $\begin{array}{c}\text { Confirmed } \\
\text { Cases }\end{array}$ & $\begin{array}{c}\text { Active } \\
\text { Cases }\end{array}$ & Deaths & Recoveries \\
\hline AJK & 22,116 & 1,520 & 601 & 19,995 \\
\hline Balochistan & 29,110 & 1,530 & 319 & 27,261 \\
\hline GB & 7,414 & 865 & 117 & 6,432 \\
\hline Islamabad & 84,722 & 2,057 & 787 & 81,878 \\
\hline KPK & 140,818 & 2,288 & 4,386 & 134,144 \\
\hline Punjab & 350,618 & 9,981 & 10,881 & 329,756 \\
\hline Sindh & 356,929 & 30,609 & 5,720 & 320,600 \\
\hline
\end{tabular}

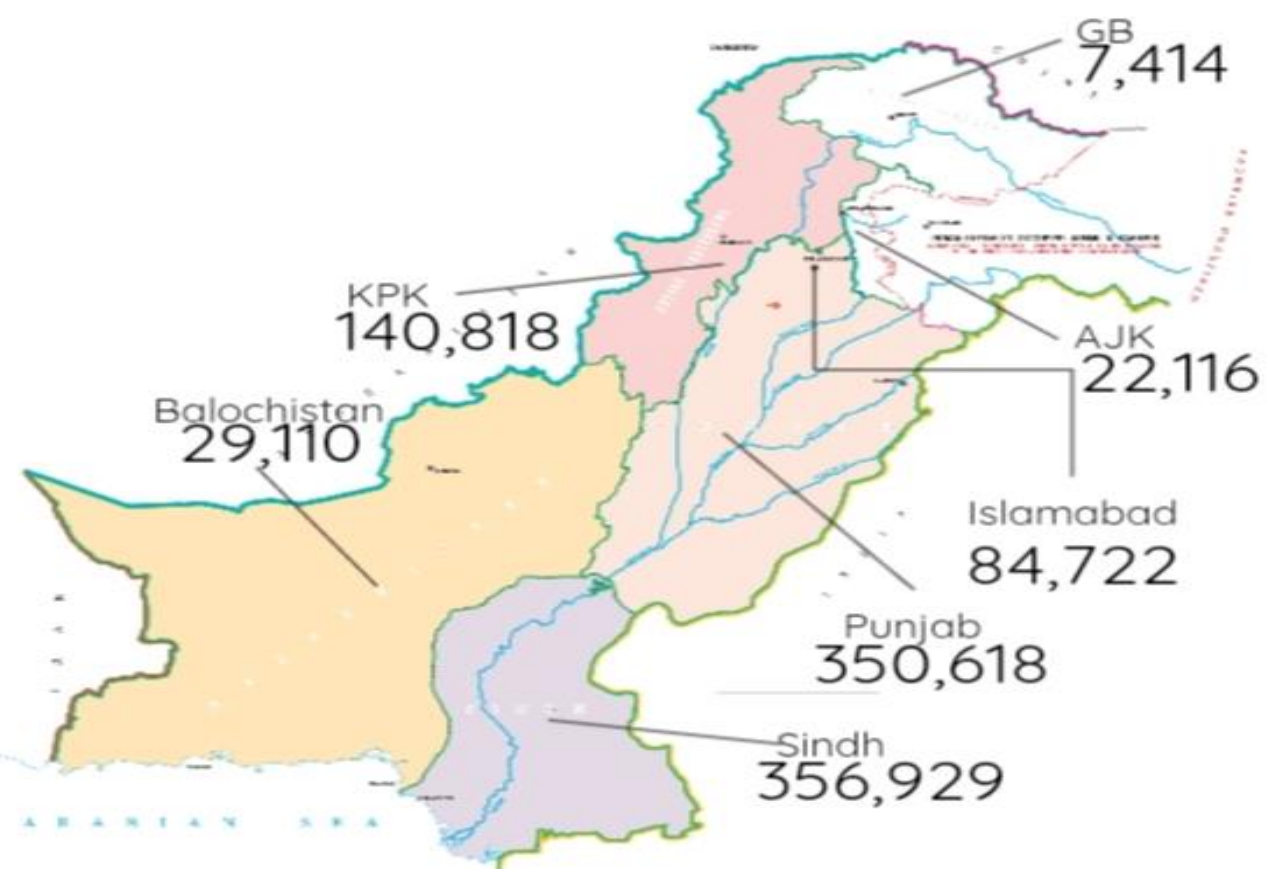

Figure 2: Current situation of Pakistan (July 19, 2021-07:59am) 


\section{International Journal of Engineering Applied Sciences and Technology, 2021 Vol. 6, Issue 3, ISSN No. 2455-2143, Pages 62-67 \\ Published Online July 2021 in IJEAST (http://www.ijeast.com)}

\section{PAKISTAN COVID -19 VACCINATIONS}

Pakistan has so far approved six Covid vaccines Sinopharm, Cansino, Sinovic, sputnik, AstraZeneca, and Moderna (mRna-1273). ${ }^{8}$

Pakistan began its COVID -19 vaccines on February 3 starting with frontline healthcare workers and touched the 1 million mark by April 6. It took around 60 days to reach the first million and about the same time ( 2 months) to administer another 9 million doses indicating a major vaccine rollout. ${ }^{6}$ Pakistan immunization campaign is slow due to shortage of vaccines but the picked pace last month as the country started producing single Dose Chinese CanSino vaccine, the hope of making 3 million Doses a month. Around 250,000 Doses a day are being administered currently. ${ }^{6}$ Pakistan is vaccinating all adult citizens (18 years and above) free of cost at
Government health facility. Now government of Pakistan demand vaccination certificate from Government employees, teachers, restaurants, passengers etc. ${ }^{11}$ on $17^{\text {th }}$ July $1,236,000$ million doses of AstraZeneca COVID-19 vaccine reached Islamabad through COVAX. ${ }^{12}$

Since May, 2.4 million Doses of AstraZeneca ${ }^{12}$, 100,160 doses of Pfizer and 2.5 million Doses of Moderna. ${ }^{7}$ Pakistan presently has 172 COVID-19 labs with the capacity of conducting 80,000 tests per day. In Pakistan vaccination 18 above peoples start $\mathbf{3}$ June. ${ }^{9}$ Islamabad 4 July2021, today 2.5 million doses of Moderna (mRNA-1273) Covid-19 vaccine supplied through the COVAX facility dose sharing mechanism and donated by united state. Islamabad 17 July 2021-today 1,236000 million doses of AstraZeneca Covid -19 vaccine reached Islamabad. ${ }^{9}$
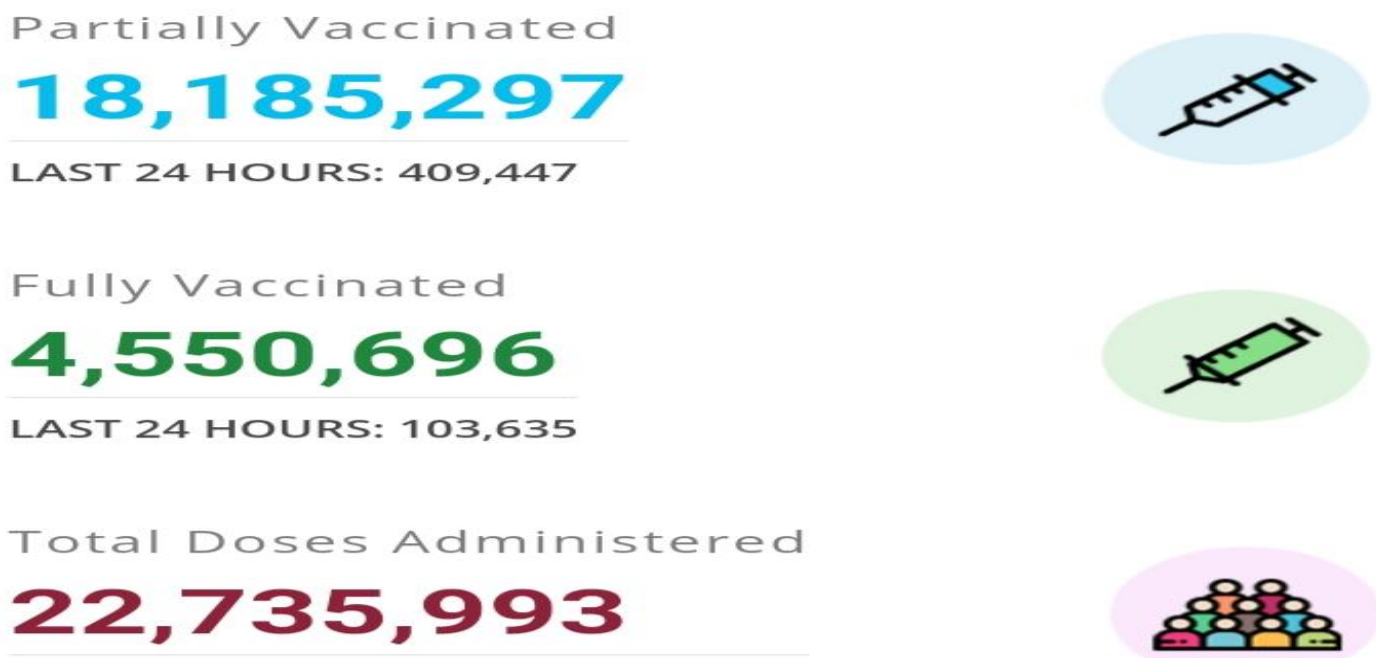

LAST 24 HOURS: 513,082

Figure 3: Vaccination status in Pakistan (July 19, 2021-07:59am) 


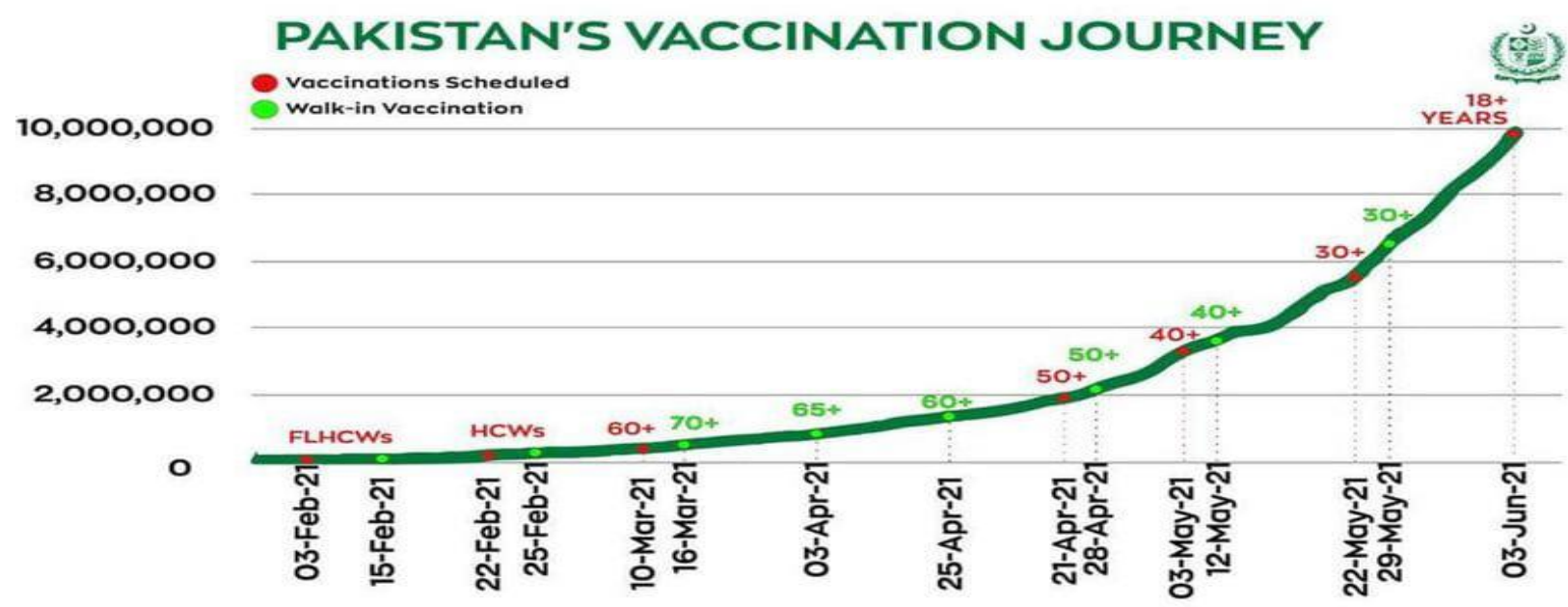

10 million COVID-19 vaccine doses administered in Pakistan!

Fig: 3 COVID-19 Vaccination journey

\section{RESULTS AND DISCUSSION}

As the result COVID-19 cases increases due to traveling from one country to another country. Pakistan trade and travel with other countries like Afghanistan, Iran, and China. In Pakistan COVID-19 cases is high due to importation and traveling meet other peoples that suffer in diseases. Pakistan needs to be high and good precautions follow rules and strict step to identify the COVID-19 cases. Due to progress of COVID-19 Pakistan economy is under greater impact. Our country cannot bear lockdown, and lockdown should extend. Pakistan suffering economic loss, and does not have sufficient resources to provide the COVID patient at the time of positive report. The prime minister call the community meeting dealing with pandemic that decided peoples avoid events, and gatherings wearing masks, avoid crowed and low risk of infection by reducing rate of contact with other peoples.

\section{CONCLUSION AND RECOMMENDATIONS}

COVID-19 is swiftly spreading very fast. Within few days the mortality rate increases at high level. Clinics hospitals are working to invent COVID-19 vaccines that are very helpful to prevent this disease. If we take step self isolation, that control the chance of spreading COVID-19. Each individuals and world health organization centre has a tremendous potential for public health, different sectors working together face the challenge along with policy initiatives. COVID-19 vaccinations patients got two intramuscular injections, 21-28 days separated conveyed in the deltoid muscle. These vaccinations are very helpful, and decrease mortality rate.

\section{RECOMMENDATIONS}

1) Clean your hands, by using soaps, alcohol, and hand sanitizer.

2) Maintain distance, from anyone who suffering disease sneezing and coughing.

3) Wearing a mask

4) Avoid touching your hands on face, mouth and eyes.

5) Stay home if u feel uncomfortable, and unwell.

6) If you have a fever, cough, sneezing and problem in breathing then immediately seek medical attention.

7) Mask can help to prevent the spreading of COVID-19 disease; don't wear the mask to others that they do not protect from this dangerous disease and should be combined with physical distancing.

8) Vaccination 


\section{International Journal of Engineering Applied Sciences and Technology, 2021 Vol. 6, Issue 3, ISSN No. 2455-2143, Pages 62-67 \\ Published Online July 2021 in IJEAST (http://www.ijeast.com)}

\section{REFERENCES}

1- World Health Organization. Coronavirus disease 2019(COVID-19), Situation Report-80. https://www.who.int/docs/defaultsource/coronaviruse/situationreports/20200409-sitrep-80-covid19.pdf?sfvrsn=1b685d64_6. Published April 9, 2020. Accessed April 10, 2020.

2- World Health Organization. (n.d.). Naming the CORONAVIRUS disease (COVID-19) and the virus that causes it. World Health Organization. https://www.who.int/emergencies/diseases/nove 1-coronavirus-2019/technical-guidance/namingthe-coronavirus-disease-(covid-2019)-and-thevirus-that-causes-it. Accessed July 19, 2021.

3- (PDF) progress of COVID-19 epidemic in Pakistan. (n.d.). https://www.researchgate.net/publication/35104 4878_Progress_of_COVID19_Epidemic_in_Pakistan.

4- Softnio. (n.d.). 19 situation! COVID. https://covid.gov.pk/.

5- World Health Organization. Pakistan: COVID19-Situation update as of 19 July 2021 (7:59 am). Updates: Ministry of National Health Services Regulations and Coordination Dashboard; 2021

6- Sana Jamal, C. (2021, June 13). COVID-19: How PAKISTAN plans to vaccinate its way out of pandemic. Pakistan - Gulf News. https://gulfnews.com/world/asia/pakistan/covid19-how-pakistan-plans-to-vaccinate-its-wayout-of-pandemic-1.79881131. Accessed 19 July, 2021

7- Another 1.2 million doses of COVID-19 VACCINE reach Pakistan through COVAX. UNICEF. (2021, July 30). https://www.unicef.org/pakistan/pressreleases/another-12-million-doses-covid-19vaccine-reach-pakistan-through-covax. Accessed July 19, 2021.

8- 2.5 million doses of COVID-19 vaccine supplied through COVAX start being rolled out in Pakistan - Pakistan. ReliefWeb. (n.d.). https://reliefweb.int/report/pakistan/25-milliondoses-covid-19-vaccine-supplied-throughcovax-start-being-rolled-out. Accessed July 19, 2021.

9- World Health Organization. (n.d.). Eastern Mediterranean region. World Health Organization.

http://www.emro.who.int/media/news/pakistanreceives-first-consignment-of-covid-19- vaccines-via-covax-facility.html. Accessed July 19, 2021.

10- Center, N. C. O. (n.d.). National command Operation Center. National Command Operation Center. https://ncoc.gov.pk/. Accessed 19 July, 2021.

11- Shahzad, A. (2021, July 29). Pakistan demands proof of vaccine for School, Resturant, and transport staff. Reuters. https://www.reuters.com/world/china/pakistanban-public-sector-education-malls-air-travelunvaccinated-2021-07-29/.

12- United Nations. (n.d.). Media Update: united Nations Pakistan, 17 July 2021 in Pakistan. United Nations. https://pakistan.un.org/index.php/en/136475media-update-united-nations-pakistan-17-july2021. Accessed July 19, 2021. 